\title{
Effects of Feeding Fish Meal and n-3 Fatty Acids on Ovarian and Uterine Responses in Early Lactating Dairy Cows
}

\author{
A. R. Heravi Moussavi, ${ }^{\star}$ R. O. Gilbert,† T. R. Overton,‡ D. E. Bauman,‡ and W. R. Butler ${ }^{1}$ \\ *Department of Animal Science, Ferdowsi University, Mashhad 91775-1163, Iran \\ †Department of Clinical Sciences, and \\ ‡Department of Animal Science, Cornell University, Ithaca, NY 14853
}

\section{ABSTRACT}

The study was designed to test the effects of dietary supplementation with fish meal or specific n-3 fatty acids on ovarian activity and uterine responses in early lactating cows. From 5 to $50 \mathrm{~d}$ in milk (DIM), cows were fed diets that were isonitrogenous, isoenergetic, and isolipidic containing none (control), 1.25, 2.5, or 5\% menhaden fish meal (FM) or 2.3\% Ca salts of fish oil fatty acids (CaFOFA). Ovarian follicular dynamics were monitored along with plasma concentrations of estradiol and progesterone. Beginning at 23 DIM, cows were induced into a synchronized ovulatory cycle. On d 15 after ovulation (49 DIM), cows were injected with oxytocin and blood samples were collected to monitor uterine release of $\mathrm{PGF}_{2 \alpha}$ (measured as 13, 14-dihydro-15-keto $\left.\mathrm{PGF}_{2 \alpha} ; \mathrm{PGFM}\right)$. Uterine endometrial biopsies were collected for fatty acid analysis and cyclooxygenase-2 (COX-2) protein measurement. Ovarian follicular activities as well as plasma estradiol and progesterone concentrations were similar across diets. Endometrial fatty acid composition of eicosapentaenoic acid (C20:5, n-3) and docosahexaenoic acid (C22:6, n-3) were increased as much as 3 -fold by supplementation with fish meal and CaFOFA. Conjugated linoleic acid (C18:2 cis-9, trans-11) in the endometrium was also increased; conversely, arachidonic acid (C20:4, n-6) percentage was decreased by $5 \%$ FM. Plasma PGFM response to oxytocin injection was not different among diets and endometrial COX-2 protein abundance did not differ. Results from this experiment demonstrate that dietary supplementation with fish meal or n-3 fatty acids in early lactating dairy cows significantly increased uterine $\mathrm{n}$ 3 fatty acid concentrations, but had no apparent effect on endometrial COX-2 or $\mathrm{PGF}_{2 \alpha}$ production in response to oxytocin challenge.

Key words: cow, fish meal, cyclooxygenase-2 protein, n-3 fatty acids

Received December 10, 2005.

Accepted August 14, 2006.

${ }^{1}$ Corresponding author: wrb2@cornell.edu

\section{INTRODUCTION}

Prostaglandins influence many processes throughout the body including ovarian activity and follicle development and are well known for their effects on corpus luteum (CL) function (Robinson et al., 2002). Arachidonic acid (ARA), an essential fatty acid present in membrane phospholipids, is the primary precursor of prostaglandins. Cyclooxygenase-2 (COX-2), a rate-limiting enzyme, oxidizes ARA to prostaglandin $\mathrm{H}_{2}$ $\left(\mathbf{P G H}_{2}\right)$, which is the precursor of all other prostaglandins including $\mathrm{PGF}_{2 \alpha}$ and $\mathrm{PGE}_{2}$. Bovine endometrium secretes $\mathrm{PGF}_{2 \alpha}$ during the estrous cycle (Danet-Desnoyers et al., 1995) and pulsatile secretion seems to mediate CL regression (McCracken et al., 1999). Expression of COX-2 mRNA and protein were found to be at low and high levels on $d 1$ to 12 and 13 to 21 of the estrous cycle, respectively (Arosh et al., 2002). Polyunsaturated fatty acids such as linoleic, linolenic, eicosapentaenoic (EPA), and docosahexaenoic (DHA) may inhibit uterine $\mathrm{PGF}_{2 \alpha}$ synthesis through mechanisms such as decreased availability of the precursor ARA, increased competition by these fatty acids with ARA for binding to PGH synthase, and inhibition of PGH synthase synthesis or activity (Mattos et al., 2000). In vitro studies showed that the n-3 fatty acids EPA and DHA altered prostaglandin biosynthesis in a number of cells and tissues (Weber and Sellmayer, 1991; Mattos et al., 2003). The most potent COX-2 inhibitor was EPA followed by DHA (Ringbom et al., 2001). In another study, isomers of conjugated linoleic acid (CLA) also inhibited $\mathrm{PGF}_{2 \alpha}$ synthesis and the effect was independent of the concentration of linolenic acid and n-6:n-3 ratio (Harris et al., 2001).

Fish meal (FM) has relatively large concentrations of 2 polyunsaturated fatty acids, EPA (C20:5, n-3) and DHA (C22:6, n-3) and so FM or fish oil fatty acids in the diet may alter uterine $\mathrm{PGF}_{2 \alpha}$ synthesis. Inhibiting uterine secretion of $\mathrm{PGF}_{2 \alpha}$ by feeding EPA and DHA may delay regression of the CL and increase fertility by improving embryo survival (Burke et al., 1997; Staples et al., 1998; Mattos et al., 2000).

Evidence for the incorporation of DHA (Mattos et al., 2004) and EPA (Burns et al., 2003; Mattos et al., 2004) 
Table 1. Fatty acid composition ( $\mathrm{g} / 100 \mathrm{~g}$ of fatty acids) of the diets containing fish meal (FM) and Ca salts of fish oil fatty acids (CaFOFA)

\begin{tabular}{|c|c|c|c|c|c|}
\hline \multirow[b]{2}{*}{ Fatty acid } & \multicolumn{5}{|c|}{ Diet } \\
\hline & Control & $\begin{array}{l}1.25 \% \\
\text { FM }\end{array}$ & $\begin{array}{l}2.5 \% \\
\text { FM }\end{array}$ & $\begin{array}{l}5 \% \\
\text { FM }\end{array}$ & $\begin{array}{l}2.3 \% \\
\text { CaFOFA }\end{array}$ \\
\hline C14:0 & 0.27 & 0.32 & 0.39 & 0.43 & 0.42 \\
\hline $\mathrm{C} 16: 0$ & 18.59 & 18.98 & 18.98 & 18.95 & 18.89 \\
\hline C18:0 & 3.31 & 3.31 & 3.30 & 3.34 & 3.33 \\
\hline C18: 1 , cis -9 & 22.74 & 22.43 & 22.30 & 22.20 & 22.18 \\
\hline $\mathrm{C} 18: 2$, cis -9, cis -12 & 38.25 & 38.10 & 38.00 & 37.81 & 38.12 \\
\hline $\mathrm{C} 18: 3$, cis -9, cis -12, cis -15 & 8.57 & 8.56 & 8.56 & 8.57 & 8.60 \\
\hline $\mathrm{C} 20: 5$ & - & 0.01 & 0.03 & 0.09 & 0.03 \\
\hline $\mathrm{C} 22: 6$ & - & 0.02 & 0.04 & 0.11 & 0.03 \\
\hline Others & 8.26 & 8.26 & 8.41 & 8.50 & 8.40 \\
\hline
\end{tabular}

into uterine lipids by feeding FM to cows has been reported. On the other hand, results from adding FM to the diet to reduce endometrial $\mathrm{PGF}_{2 \alpha}$ production are inconsistent. Mattos et al. (2002) showed that feeding FM to lactating cows reduced secretion of $\mathrm{PGF}_{2 \alpha}$, whereas Wamsley et al. (2005) observed that FM supplementation had no effect on the secretion of $\mathrm{PGF}_{2 \alpha}$ in nonlactating heifers having normal progesterone concentrations and only decreased $\mathrm{PGF}_{2 \alpha}$ in those having reduced progesterone. In tissue cultures, net inhibition of endometrial $\mathrm{PGF}_{2 \alpha}$ biosynthesis by $\mathrm{n}-3$ fatty acids seems to vary depending upon the ratio of n-6 to n-3 fatty acids (Caldari-Torres et al., 2006).

The objective of the current study was to determine the effects of dietary supplementation with FM or specific $\mathrm{n}-3$ fatty acids from fish oil on ovarian follicular activity and $\mathrm{PGF}_{2 \alpha}$ production by the uterus in early lactating cows approaching the breeding period.

\section{MATERIALS AND METHODS}

\section{Cows, Diets, and Sampling Procedures}

From 5 to 50 DIM, 31 multiparous cows were housed in tie stalls and fed diets containing none $(\mathrm{n}=6), 1.25 \%$ $(\mathrm{n}=6), 2.5 \%(\mathrm{n}=6)$, or $5 \%(\mathrm{n}=6)$ menhaden FM (SeaLac, Omega Protein, Hammond, LA) or $2.3 \%$ Ca salts of fish oil fatty acids (CaFOFA; EnerGII Repro; Virtus Nutrition, Fairlawn, $\mathrm{OH} ; \mathrm{n}=7$ ). Diets were formulated to be isonitrogenous, isoenergetic, and isolipidic (adjusted to 5\% lipid with Ca salts of palm oil fatty acids, EnerGII; Virtus Nutrition). In addition, diets were formulated to provide similar amounts of $\mathrm{MP}, \mathrm{NE}_{\mathrm{L}}(1.78$ $\mathrm{Mcal} / \mathrm{kg}$ ), and NFC (42\%) using the Cornell Net Carbohydrate and Protein System (Fox et al., 2004). Concentrate mixtures and forage sources were combined in a weighing and mixing unit (American Calan, Inc., Northwood, NH) and fed once daily at $0930 \mathrm{~h}$ to allow 5 to $10 \%$ orts (as-fed basis). The TMR were sampled weekly throughout the experiment and DM content was determined by drying at $110^{\circ} \mathrm{C}$ for $18 \mathrm{~h}$. Ingredients were sampled weekly, composited monthly, and analyzed for fatty acids. Fatty acid composition of the diets is listed in Table 1. Fatty acid composition for the 2 commercial fat supplements and FM as provided by suppliers are listed in Table 2. Details on diet composition, feed intake, milk yield, and metabolic responses are reported in the companion paper (Heravi Moussavi et al., 2007). The Cornell University Institutional Animal Care and Use Committee approved all procedures involving cows.

\section{Blood Collection and Analyses}

Blood samples were collected daily from d 1 to 50 postpartum via venipuncture of coccygeal vessels before the morning feeding. Plasma was separated immediately by centrifugation $(20 \mathrm{~min}$ at $1,000 \times \mathrm{g})$ and stored

Table 2. Fatty acid composition (g/100 g of fatty acids) in dietary fat supplements: EnerGII, EnerGII Repro, and fish meal (FM)

\begin{tabular}{lccc}
\hline Fatty acid & & $\begin{array}{c}\text { EnerGII } \\
\text { Repro }^{2}\end{array}$ & FM $^{3}$ \\
\hline <C16:0 & 2.00 & 2.62 & 11.39 \\
Palmitic, C16:0 & 46.47 & 40.98 & 20.77 \\
Palmitoleic, C16:1 & - & - & 12.42 \\
Stearic, C18:0 & 4.43 & 4.23 & 8.36 \\
Oleic, C18:1 & 35.48 & 30.88 & 9.65 \\
Vaccenic, C18:1 & 0.75 & 1.21 & - \\
Other isomers, C18:1 & 0.27 & 0.55 & - \\
Trans isomers, C18:2 & 0.11 & 0.14 & - \\
Linoleic, C18:2 & 8.81 & 8.04 & 1.69 \\
Linolenic, C18:3 & - & 0.54 & 1.95 \\
Arachidic, C20:0 & 0.33 & 0.31 & 0.20 \\
Eicosenoic, C20:1 & 0.11 & 0.37 & 1.38 \\
Arachidonic, C20:4 & 0.39 & 0.35 & 2.39 \\
Eicosapentaenoic, C20:5 & - & 2.02 & 12.64 \\
Docosapentaenoic, C22:5 & - & 0.41 & 2.64 \\
Docosahexaenoic, C22:6 & - & 2.30 & 7.79 \\
Others & 1.08 & 5.08 & 6.31 \\
\hline
\end{tabular}

${ }^{1} \mathrm{Ca}$ salts of palm oil fatty acids; Virtus Nutrition, Fairlawn, $\mathrm{OH}$.

${ }^{2} \mathrm{Ca}$ salts of fish oil fatty acids; Virtus Nutrition, Fairlawn, $\mathrm{OH}$.

${ }^{3}$ Menhaden fish meal; Omega Protein, Hammond, LA. 
at $-20^{\circ} \mathrm{C}$. Estradiol- $17 \beta$ was measured by RIA in samples collected during the first 24 DIM (Serono Maia, Cortlandt Manor, NY) as described previously (Beam and Butler, 1997). Progesterone concentrations were quantified daily from d 10 to 50 by RIA as described previously (Elrod and Butler, 1993). Total cholesterol was measured every $10 \mathrm{~d}$ by colorimetric methods (Beam and Butler, 1997) using a commercial kit (Diagnostic Chemicals Limited, Charlottetown, Prince Edward Island, Canada).

\section{Monitoring Ovarian Follicular Activity}

Ultrasound measurements of follicular activity were made on alternate days from d 10 to 23 to ascertain the characteristics and fate of the first follicular wave, using a 7.5-MHz rectal transducer (Aloka 210; Corometrics Medical System Inc., Wallingford, CT). Dominant follicle development was characterized by follicular mapping of recorded ultrasound images (Beam and Butler, 1997). Follicular recruitment during the first follicular wave after parturition was evaluated by quantification of the numbers of 5- to $10-\mathrm{mm}$ follicles on $\mathrm{d} 10$ and 14 (Robinson et al., 2002). A dominant follicle was defined as a follicle that was $>10 \mathrm{~mm}$ in diameter in the absence of other large $(>9 \mathrm{~mm})$ growing follicles. All ovulations detected by ultrasound were confirmed by analysis of plasma progesterone.

\section{Synchronization of the Estrous Cycle}

Cows were synchronized for ovulation beginning on d 23 with injection (i.m.) of $100 \mu \mathrm{g}$ of $\mathrm{GnRH}$ (Cystorelin; Merial Ltd., Athens, GA) followed in $7 \mathrm{~d}$ with $30 \mathrm{mg}$ of $\mathrm{PGF}_{2 \alpha}$ (Lutalyse; Pfizer, New York, NY), followed in 48 $\mathrm{h}$ by a second injection of GnRH (d 0 of synchronized cycle). An intravaginal insert delivering progesterone (CIDR; InterAg, Hamilton, NZ) was inserted during the $7 \mathrm{~d}$ between the first injection of $\mathrm{GnRH}$ and $\mathrm{PGF}_{2 \alpha}$ to better ensure ovulation in each lactating cow (Yavas et al., 1999).

\section{Monitoring Uterine Conditions}

On d 15 of the synchronized estrous cycle $(49.3 \pm 2.4$ DIM), cows were injected intravenously at $1300 \mathrm{~h}$ with $100 \mathrm{IU}$ of oxytocin (Butler Co., Columbus, OH). Using indwelling jugular catheters placed the day before, blood samples were collected at 15-min intervals from $1 \mathrm{~h}$ before until $3 \mathrm{~h}$ after the oxytocin injection and at 30-min intervals from 3 to $4 \mathrm{~h}$ postinjection to monitor uterine secretion of $\mathrm{PGF}_{2 \alpha}$. Plasma concentration of 13,14-dihydro-15-keto $\mathrm{PGF}_{2 \alpha}$ (PGFM), a product of $\mathrm{PGF}_{2 \alpha}$ metabolism, was assayed by using a RIA procedure described previously (Meyer et al., 1995).
Uterine endometrial biopsies were collected immediately after completion of the oxytocin challenge and blood sampling sequence by passing a biopsy tool through the cervix and into the uterine horn ipsilateral to the CL by using transrectal manipulation. No previous manipulation of the uterus had occurred before biopsy. The open jaws of the biopsy basket $(2 \times 1 \mathrm{~mm})$ were pressed against the endometrium and samples (approximately $100 \mathrm{mg}$ ) of endometrium were removed. Uterine samples were washed with PBS (0.05 $M$ $\mathrm{NaPO}_{4}, \mathrm{pH}$ 7.2), plunged into liquid nitrogen, and stored at $-80^{\circ} \mathrm{C}$.

\section{Liver Tissue Biopsy}

To confirm absorption of dietary fatty acids and availability to the body tissues, liver biopsy samples were collected on d 21 as previously described (Butler et al., 2003). The liver samples were washed with PBS and blotted dry, plunged into liquid nitrogen, and stored at $-80^{\circ} \mathrm{C}$.

\section{Fatty Acid Analysis}

Total fat content of the TMR was extracted using ether (Foss Tecator Soxtec System, Foss North America, Eden Prairie, MN; application subnote AN 3414; Dairy One Cooperative Inc., Ithaca, NY). Uterine and liver tissues were homogenized and lipids were extracted by the procedure of Hara and Radin (1978) by using a mixture of hexane and isopropanol. Following extraction, fatty acids in the samples were methylated (Chouinard et al., 1999) and methyl esters were analyzed by gas chromatography (GCD system HP 6890+; Hewlett Packard, Avondale, PA) equipped with a CPSil 88 capillary column $[100 \mathrm{~m} \times 0.25 \mathrm{~mm}$ (internal diameter) with $0.2-\mu \mathrm{m}$ film thickness; Varian, Walnut Creek, CA]. A programmed temperature run was used: the oven temperature was initially maintained at $70^{\circ} \mathrm{C}$ for $2 \mathrm{~min}$, then increased at $8^{\circ} \mathrm{C} / \mathrm{min}$ to $110^{\circ} \mathrm{C}$, and held for $4 \mathrm{~min}$. The temperature was then increased at $5^{\circ} \mathrm{C} /$ min to $170^{\circ} \mathrm{C}$ and held for $10 \mathrm{~min}$. Finally it was increased at $4^{\circ} \mathrm{C} / \mathrm{min}$ to $225^{\circ} \mathrm{C}$ and held for $15 \mathrm{~min}$. Injector and detector temperatures were maintained at $250^{\circ} \mathrm{C}$. The split ratio was $100: 1$, and hydrogen was used as the carrier gas at $2.1 \mathrm{~mL} / \mathrm{min}$. Fatty acid methyl ester standards were used to identify each compound in samples.

\section{Western Blot}

Western blots were used for quantifying the COX-2 protein. Endometrial biopsy samples were minced using a surgical blade and thoroughly homogenized in 
radioimmunoprecipitation buffer $(40 \mathrm{~m} M$ Tris-HCl, 274 $\mathrm{m} M \mathrm{NaCl}, 20 \%$ glycerol, $2 \%$ Nonidet P-40, $0.2 \%$ SDS, $1 \%$ Na-deoxycholate, $1 \mathrm{~m} M$ EDTA, pH 8) using a pellet pestle. Just before lysis, the following protease inhibitors were added: $25 \mathrm{~m} M \beta$-glycerophosphate, $5 \mathrm{~m} M$ benzamidine, $200 \mu M$ phenylmethylsulfonyl fluoride, $1 \mu M$ leupeptin, and $1 \mu M$ pepstatin (Sigma Chemical, St. Louis, MO). Lysates were cleared by centrifugation $\left(1,500 \times g, 10 \mathrm{~min}, 4^{\circ} \mathrm{C}\right)$. Total protein in the resulting cleared lysate was quantified (BioRad DC Protein Assay, BioRad Laboratories Inc., Hercules, CA). Proteins were denatured in loading buffer (40\% SDS, $10 \%$ $1 M$ Tris, $20 \%$ glycerol, $0.013 \%$ bromophenol blue) at $95^{\circ} \mathrm{C}$ for $3 \mathrm{~min}$. Approximately $30 \mu \mathrm{g}$ of total protein was loaded in each lane and electrophoresed on 6\% SDS polyacrylamide gels (SDS-PAGE) at $150 \mathrm{~V}$. Prestained protein markers (BioRad Precision Plus Protein Standards All Blue, BioRad Laboratories Inc.) were loaded as molecular weight standards onto each gel. The separated proteins were then transferred onto Polyscreen PVDF transfer membranes (PerkinElmer, Wellesley, MA) by transfer tank (Hoefer Scientific Instruments, San Francisco, CA) at $200 \mathrm{~mA}$ and $4^{\circ} \mathrm{C}$. Proteins were blocked at $4^{\circ} \mathrm{C}$ with blocking buffer [1\% NDM powder and 1\% BSA in TBST buffer (10 $\mathrm{mM}$ Tris-HCl, 150 $\mathrm{m} M \mathrm{NaCl}, 0.5 \%$ Tween-20, $\mathrm{pH}$ 7.6)]. The blots were incubated with primary antibody (Polyclonal Rabbit AntiHuman PGHS-2; Oxford Biomedical Research Inc., Oxford, MI) overnight at a dilution of 1:1,000 in the blocking buffer. Blots were washed 3 times at 10-min intervals in TBST and then incubated with secondary antibody (Goat AntiRabbit IgG Horseradish Peroxidase Conjugate; BioRad Laboratories) for $2 \mathrm{~h}$ at room temperature at a dilution of 1:5,000 in the blocking buffer. Then, blots were washed 4 times for 15 min each in TBST and chemiluminescence reagent containing luminol (PerkinElmer) was applied. Blots were exposed to Kodak X-OMAT Blue autoradiography film (Rochester, $\mathrm{NY}$ ), the signal intensity was quantified by ImageJ 1.29x (Wayne Rasband, National Institutes of Health, Bethesda, MD), and expressed in arbitrary units.

\section{Statistical Analyses}

Data that were repeated in time were analyzed by using a mixed model (PROC MIXED, SAS Institute Inc., Cary, NC) for a completely randomized design with repeated measures using the following model:

$$
\mathrm{Y}_{\mathrm{ijk}}=\mu+\mathrm{T}_{\mathrm{i}}+\mathrm{A}_{(\mathrm{i}) \mathrm{j}}+\mathrm{D}_{\mathrm{k}}+(\mathrm{T} \times \mathrm{D})_{\mathrm{ik}}+\varepsilon_{\mathrm{ijk}}
$$

where $\mathrm{Y}_{\mathrm{ijk}}=$ dependent variable, $\mu$ = overall mean, $\mathrm{T}_{\mathrm{i}}=$ treatment effects, $\mathrm{A}_{(\mathrm{i}) \mathrm{j}}=$ random effects of animal within treatments, $\mathrm{D}_{\mathrm{k}}=$ effects of sampling date or time, $(\mathrm{T} \times$
$\mathrm{D})_{\mathrm{ik}}=$ interaction effects of treatment and sampling date or time, and $\varepsilon_{\mathrm{ik}}=$ residual error associated with the ijk observation.

Overall effect of treatment was tested using cow within treatment as the error term. Means were separated by Tukey-Kramer multiple range tests. Because of the requisite facilitative effect of plasma progesterone concentration on endometrial $\mathrm{PGF}_{2 \alpha}$ production (Wamsley et al., 2005), PGFM data were also analyzed using plasma progesterone concentration on the day of oxytocin challenge as covariate. Three cows without a functional CL on $\mathrm{d} 15$ of the synchronized cycle were removed from all PGFM and COX-2 analyses.

Data that were not repeated in time were analyzed by using a generalized linear model (PROC GLM, SAS Inst. Inc.) for a completely randomized design using the following model:

$$
\mathrm{Y}_{\mathrm{ij}}=\mu+\mathrm{T}_{\mathrm{i}}+\varepsilon_{\mathrm{ij}}
$$

where $\mathrm{Y}_{\mathrm{ij}}=$ the dependent variable, $\mu$ = overall mean, $\mathrm{T}_{\mathrm{i}}=$ treatment effects, and $\varepsilon_{\mathrm{ij}}=$ residual error.

Means were separated by Duncan multiple range test. Area under the curve (AUC) for PGFM was calculated using the statistical software package, NCSS 2000 (NCSS, Kaysville, UT). One cow fed the 5\% FM diet required treatment for ketosis from d 10 to 40 of lactation and was subsequently dropped from all analyses and the study.

\section{RESULTS}

All cows except one displayed an early wave of ovarian follicular development characterized by emergence of a large dominant follicle during the second postpartum week. Effects of diet on characteristics of follicular development are summarized in Table 3. A diet effect $(P<0.01)$ on the number of medium-sized follicles $(5$ to $10 \mathrm{~mm}$ ) present was detected at $\mathrm{d} 10 \mathrm{in}$ which number of follicles in cows fed 5\% FM was greater than that in cows fed the remaining diets. Diameter of the first dominant follicle on $\mathrm{d} 10$ and 14 , maximum diameter of the first dominant follicle, and number of days until detection of a follicle $\geq 10 \mathrm{~mm}$ in diameter did not differ among diets. Follicle size on the day preceding synchronized ovulation (day of second $\mathrm{GnRH}$ ) also was not affected by diet $(14.9 \pm 0.8 \mathrm{~mm}$, mean $\pm \mathrm{SE})$. Only 5 cows $(2,1$, and 2 cows fed control, $1.25 \% \mathrm{FM}$, and CaFOFA diets, respectively) ovulated a first-wave follicle before 23 DIM.

Plasma estradiol concentrations decreased $(P<$ 0.001 ) from calving until $\mathrm{d} 7$ for cows in all diets. Mean concentrations on $\mathrm{d} 7$ to 24 did not differ among diets (data not shown; no treatment $\times$ time interaction). Ex- 
Table 3. Ovarian follicles and development during the first postpartum follicular wave in cows fed diets containing fish meal (FM) and Ca salts of fish oil fatty acids (CaFOFA)

\begin{tabular}{lllllll}
\hline & \multicolumn{5}{c}{ Diet } \\
\cline { 2 - 5 } & Control & $\begin{array}{l}1.25 \% \\
\text { FM }\end{array}$ & $\begin{array}{l}2.5 \% \\
\text { FM }\end{array}$ & $\begin{array}{l}5 \% \\
\text { Item }\end{array}$ & $\begin{array}{l}\text { FM } \\
\text { CaFOFA }\end{array}$ & SE \\
\hline $\begin{array}{l}\text { Number of follicles (5 to } 10 \mathrm{~mm} \text { in } \\
\text { diameter) on d 10 }\end{array}$ & $1.7^{\mathrm{a}}$ & $2.0^{\mathrm{a}}$ & $2.0^{\mathrm{a}}$ & $3.8^{\mathrm{b}}$ & $1.8^{\mathrm{a}}$ & 0.3 \\
$\begin{array}{l}\text { Maximum diameter of first dominant } \\
\text { follicle on d 10, mm }\end{array}$ & 9.1 & 8.9 & 7.6 & 10.1 & 9.9 & 1.5 \\
$\begin{array}{l}\text { Maximum diameter of first dominant } \\
\text { follicle on d 14, mm }\end{array}$ & 13.0 & 12.7 & 11.2 & 14.5 & 13.3 & 1.9 \\
$\begin{array}{l}\text { Maximum diameter of first dominant } \\
\text { follicle, mm }\end{array}$ & 15.6 & 15.3 & 16.7 & 19.6 & 18.4 & 2.6 \\
$\begin{array}{c}\text { Number of days until detection of a } \\
\text { follicle } \geq 10 \text { mm in diameter }\end{array}$ & 10.6 & 11.0 & 13.1 & 9.8 & 10.8 & 1.8 \\
\hline
\end{tabular}

${ }^{\mathrm{a}, \mathrm{b}}$ Means within a row that lack a common superscript letter differ $(P<0.05)$.

cept for the several cows that ovulated, plasma progesterone remained undetectable during the postpartum period until insertion of the CIDR. Plasma progesterone concentrations did not differ among diets (no treatment $\times$ time interaction) during the luteal phase following synchronized ovulation. Progesterone in all cows averaged $4.6 \pm 0.4 \mathrm{ng} / \mathrm{mL}$ on the day of oxytocin challenge. In addition, progesterone AUC was not different in cows among diets. Plasma concentrations of cholesterol were not affected by diet, but increased $(P<0.001)$ linearly over time to its greatest concentration near the end of the experiment $(2.5 \pm 0.1 \mathrm{vs} .4 .3 \pm 0.1 \mathrm{mmol} / \mathrm{L}$ for $\mathrm{d} 15$ and 45 , respectively, in all cows).

In liver, concentration of DHA and CLA (C18:2, cis9 , trans-11) was affected $(P<0.05)$ by diet. Concentration of DHA was greatest for cows fed $5 \% \mathrm{FM}$, whereas CLA was greatest in cows on the CaFOFA diet (Table 4). Liver content of ARA (C20:4) was similar among diets (Table 4), as were concentrations of linoleic (C18:2, cis-9, cis-12) and linolenic acids (C18:3).

Endometrial content of EPA and DHA (\% of total fatty acids) was affected by diet and increased $(P<0.01)$ with increasing FM (Table 5). Concentrations of EPA and DHA in cows fed the $2.3 \%$ CaFOFA diet were similar to those fed the $2.5 \% \mathrm{FM}$ diet. Concentration of CLA in endometrial tissue also was increased $(P<0.01)$ by $5 \% \mathrm{FM}$ and CaFOFA (Table 5). Total n-3 fatty acids (linolenic + EPA + DHA) and the n-6:n-3 ratio differed $(P<0.01)$ among diets, with $5 \% \mathrm{FM}$ having the greatest n-3 fatty acid content and least n-6:n-3 ratio. Arachidonic acid was decreased $(P<0.05)$ by the $5 \%$ FM diet. Endometrial linolenic acid concentrations were affected $(P<0.05)$ by diet and $5 \% \mathrm{FM}$ had the greatest concentration. Linoleic acid concentrations were similar across diets.

Based on plasma progesterone, 1 cow each fed the control and $1.25 \% \mathrm{FM}$ diet failed to ovulate and $1 \mathrm{cow}$ fed $1.25 \%$ FM had a short luteal phase. These 3 cows were deleted from the statistical comparison for plasma PGFM and endometrial COX-2. Dietary fatty acid supplementation did not affect plasma PGFM concentrations in response to oxytocin injection (Figure 1) and no treatment $\times$ time interaction was detected. On the day of oxytocin challenge, the PGFM baseline was 11.2, $5.6,6.6,6.9$, and $7.0 \mathrm{ng} / \mathrm{mL}$ (pooled $\mathrm{SE}=2.0, P=0.40$ ) and the PGFM response to oxytocin AUC was 4,185, $3,337,5,877,3,823$, and 5,138 units (pooled $\mathrm{SE}=1155$; $P<0.55$ ) for control, $1.25 \% \mathrm{FM}, 2.5 \% \mathrm{FM}, 5 \% \mathrm{FM}$, and $2.3 \%$ CaFOFA, respectively. Effect of plasma progesterone concentration as covariate for PGFM response and AUC was tested and found nonsignificant. The COX-2 protein was detected in the endometrium by Western blot and expressed in arbitrary units. Amount of endometrial COX-2 protein was similar among dietary treatments (Figure $2 ; P=0.47$ ).

\section{DISCUSSION}

The most important and striking observations in this study were the increases in EPA, DHA, and CLA percentages and also the decrease in $n-6: n-3$ ratio in uterine endometrial fatty acids without any inhibitory effect on $\mathrm{PGF}_{2 \alpha}$ secretion and endometrial COX-2 protein. The incorporation of EPA, DHA, and ARA into endometrium tissue lipids in the present study are consistent with another study (Burns et al., 2003) that showed significant changes in fatty acid composition in caruncular tissue of cows fed FM in comparison with corn gluten meal. Furthermore, we found a significant effect of diet on increased total n-3 uterine fatty acids. Mattos et al. (2004) also reported an increase of EPA and DHA in caruncular tissue collected within $12 \mathrm{~h}$ after parturition in cows that had been fed a fish oil supplement. But, in contrast to their results, we also found an increase in CLA content of uterine fatty acids when tissues were collected at 49 DIM. The increase in CLA is not unex- 
Table 4. Liver content (d 21 postpartum) of fatty acids (g/100 g of fatty acids) in cows fed diets containing fish meal (FM) and Ca salts of fish oil fatty acids (CaFOFA)

\begin{tabular}{|c|c|c|c|c|c|c|c|}
\hline \multirow[b]{2}{*}{ Fatty acid } & \multicolumn{5}{|c|}{ Diet } & \multirow[b]{2}{*}{ SEM } & \multirow[b]{2}{*}{$P$} \\
\hline & Control & $\begin{array}{l}1.25 \% \\
\text { FM }\end{array}$ & $\begin{array}{l}2.5 \% \\
\text { FM }\end{array}$ & $\begin{array}{l}5 \% \\
\text { FM }\end{array}$ & $\begin{array}{l}2.3 \% \\
\text { CaFOFA }\end{array}$ & & \\
\hline C14:0 & 3.17 & 2.74 & 2.35 & 2.39 & 2.68 & 0.32 & 0.42 \\
\hline C15:0 & 0.55 & 0.62 & 0.48 & 0.52 & 0.63 & 0.07 & 0.52 \\
\hline C16:0 & 32.94 & 31.91 & 27.93 & 30.15 & 27.23 & 2.86 & 0.55 \\
\hline C16:1 & 1.35 & 1.32 & 1.32 & 1.51 & 1.39 & 0.25 & 0.98 \\
\hline C17:0 & $0.65^{\mathrm{ab}}$ & $0.66^{\mathrm{ab}}$ & $0.64^{\mathrm{a}}$ & $0.59^{\mathrm{a}}$ & $0.82^{\mathrm{b}}$ & 0.05 & $<0.05$ \\
\hline C18:0 & 11.63 & 12.81 & 14.69 & 11.70 & 12.83 & 1.99 & 0.82 \\
\hline $\mathrm{C} 18: 1$ all trans & $1.63^{\mathrm{a}}$ & $1.68^{\mathrm{a}}$ & $1.84^{\mathrm{a}}$ & $2.28^{\mathrm{a}}$ & $4.20^{\mathrm{b}}$ & 0.37 & $<0.001$ \\
\hline $18: 1$ cis -9 & 18.66 & 19.28 & 16.79 & 19.15 & 15.90 & 1.56 & 0.43 \\
\hline $\mathrm{C} 18: 2$ cis -9, cis -12 & 9.43 & 9.08 & 10.32 & 8.99 & 10.15 & 0.94 & 0.80 \\
\hline C18:2 cis -9, trans -11 & $0.24^{\mathrm{a}}$ & $0.25^{\mathrm{a}}$ & $0.26^{\mathrm{a}}$ & $0.31^{\mathrm{ab}}$ & $0.33^{\mathrm{b}}$ & 0.02 & $<0.03$ \\
\hline C18:3 & 1.07 & 1.06 & 1.00 & 1.16 & 1.10 & 0.06 & 0.46 \\
\hline C20:0 & 0.06 & 0.01 & 0.06 & 0.03 & 0.08 & 0.04 & 0.68 \\
\hline C20:4 & 3.32 & 3.81 & 4.64 & 3.64 & 3.92 & 0.90 & 0.88 \\
\hline C20:5 & 0.54 & 0.65 & 1.11 & 1.16 & 0.98 & 0.23 & 0.26 \\
\hline C22:4 & 0.13 & 0.34 & 0.37 & 0.13 & 0.31 & 0.11 & 0.37 \\
\hline $\mathrm{C} 22: 5$ & 1.54 & 1.99 & 2.43 & 2.27 & 2.44 & 0.40 & 0.47 \\
\hline $\mathrm{C} 22: 6$ & $0.28^{\mathrm{a}}$ & $1.11^{\mathrm{ab}}$ & $2.26^{\mathrm{bc}}$ & $3.33^{\mathrm{c}}$ & $1.74^{\mathrm{ab}}$ & 0.49 & $<0.01$ \\
\hline Other & $11.79^{\mathrm{bc}}$ & $9.86^{\mathrm{a}}$ & $10.70^{\mathrm{ab}}$ & $9.93^{\mathrm{a}}$ & $12.22^{\mathrm{c}}$ & 0.48 & $<0.01$ \\
\hline $\mathrm{n}-3$ family $^{1}$ & $1.89^{\mathrm{a}}$ & $2.82^{\mathrm{ab}}$ & $4.37^{\mathrm{bc}}$ & $5.65^{\mathrm{c}}$ & $3.82^{\mathrm{abc}}$ & 0.68 & $<0.05$ \\
\hline $\mathrm{n}-6$ family $^{2}$ & 12.75 & 12.89 & 14.95 & 12.63 & 14.07 & 1.80 & 0.86 \\
\hline$n-6$ to $n-3$ ratio & $6.61^{\mathrm{d}}$ & $4.66^{\mathrm{c}}$ & $3.57^{\mathrm{b}}$ & $2.43^{\mathrm{a}}$ & $3.82^{\mathrm{b}}$ & 0.25 & $<0.01$ \\
\hline
\end{tabular}

${ }^{\mathrm{a}-\mathrm{c}}$ Means within a row that lack a common superscript letter $\operatorname{differ}(P<0.05)$

${ }^{1} \mathrm{C} 18: 3+\mathrm{C} 20: 5+\mathrm{C} 22: 6$.

${ }^{2} \mathrm{C} 18: 2$ cis -9, cis $-12+\mathrm{C} 20: 4$.

Table 5. Endometrial content of fatty acids ( $\mathrm{g} / 100 \mathrm{~g}$ of fatty acids) in cows fed diets containing fish meal (FM) and Ca salts of fish oil fatty acids (CaFOFA)

\begin{tabular}{|c|c|c|c|c|c|c|c|}
\hline \multirow[b]{2}{*}{ Fatty acid } & \multicolumn{5}{|c|}{ Diet } & \multirow[b]{2}{*}{ SEM } & \multirow[b]{2}{*}{$P$} \\
\hline & Control & $\begin{array}{l}1.25 \% \\
\text { FM }\end{array}$ & $\begin{array}{l}2.5 \% \\
\text { FM }\end{array}$ & $\begin{array}{l}5 \% \\
\text { FM }\end{array}$ & $\begin{array}{l}2.3 \% \\
\text { CaFOFA }\end{array}$ & & \\
\hline C14:0 & 0.48 & 0.42 & 0.47 & 0.50 & 0.47 & 0.10 & 0.99 \\
\hline $\mathrm{C} 15: 0$ & 0.29 & 0.26 & 0.28 & 0.29 & 0.24 & 0.03 & 0.55 \\
\hline $\mathrm{C} 16: 0$ & 15.28 & 14.62 & 14.90 & 14.94 & 14.58 & 0.69 & 0.95 \\
\hline $\mathrm{C} 16: 1$ & 0.30 & 0.23 & 0.21 & 0.23 & 0.22 & 0.05 & 0.77 \\
\hline C17:0 & 0.46 & 0.46 & 0.46 & 0.47 & 0.42 & 0.05 & 0.93 \\
\hline C18:0 & 17.55 & 17.87 & 17.87 & 16.99 & 18.10 & 0.52 & 0.65 \\
\hline C18:1 all trans & $1.49^{\mathrm{a}}$ & $1.59^{\mathrm{ab}}$ & $1.71^{\mathrm{ab}}$ & $2.15^{\mathrm{bc}}$ & $2.36^{\mathrm{c}}$ & 0.18 & $<0.01$ \\
\hline C18:1 cis-9 & 15.94 & 16.69 & 15.84 & 17.91 & 15.49 & 0.92 & 0.43 \\
\hline $\mathrm{C} 18: 2$ cis- 9, cis -12 & 14.95 & 13.86 & 15.17 & 14.87 & 15.30 & 0.91 & 0.81 \\
\hline $\mathrm{C} 18: 2$ cis -9, trans -11 & $0.20^{\mathrm{a}}$ & $0.21^{\mathrm{a}}$ & $0.24^{\mathrm{a}}$ & $0.32^{\mathrm{b}}$ & $0.33^{\mathrm{b}}$ & 0.02 & $<0.01$ \\
\hline C18:3 & $0.72^{\mathrm{ab}}$ & $0.65^{\mathrm{a}}$ & $0.70^{\mathrm{ab}}$ & $0.79^{b}$ & $0.69^{a}$ & 0.03 & $<0.05$ \\
\hline $\mathrm{C} 20: 0$ & 0.45 & 0.44 & 0.43 & 0.47 & 0.48 & 0.03 & 0.67 \\
\hline C20:4 & $13.00^{\mathrm{b}}$ & $13.75^{\mathrm{b}}$ & $12.90^{\mathrm{b}}$ & $10.25^{\mathrm{a}}$ & $12.22^{\mathrm{ab}}$ & 0.68 & $<0.05$ \\
\hline $\mathrm{C} 20: 5$ & $0.28^{\mathrm{a}}$ & $0.33^{\mathrm{a}}$ & $0.54^{\mathrm{b}}$ & $0.78^{\mathrm{c}}$ & $0.40^{\mathrm{ab}}$ & 0.05 & $<0.01$ \\
\hline $\mathrm{C} 22: 5$ & 2.41 & 2.54 & 2.83 & 3.31 & 2.73 & 0.20 & 0.06 \\
\hline $\mathrm{C} 22: 6$ & $1.11^{\mathrm{a}}$ & $1.86^{\mathrm{b}}$ & $2.23^{\mathrm{b}}$ & $3.39^{\mathrm{c}}$ & $2.15^{\mathrm{b}}$ & 0.19 & $<0.01$ \\
\hline Other & 15.07 & 14.19 & 13.19 & 12.30 & 13.80 & 0.92 & 0.34 \\
\hline n-3 family ${ }^{1}$ & $2.11^{\mathrm{a}}$ & $2.84^{\mathrm{b}}$ & $3.47^{\mathrm{b}}$ & $4.96^{\mathrm{c}}$ & $3.25^{\mathrm{b}}$ & 0.20 & $<0.01$ \\
\hline $\mathrm{n}-6$ family $^{2}$ & 27.95 & 27.61 & 28.07 & 25.13 & 27.52 & 0.96 & 0.27 \\
\hline$n-6$ to $n-3$ ratio & $13.60^{c}$ & $9.97^{\mathrm{b}}$ & $8.16^{b}$ & $5.14^{\mathrm{a}}$ & $8.78^{\mathrm{b}}$ & 0.85 & $<0.01$ \\
\hline
\end{tabular}

${ }^{a-c}$ Means within a row that lack a common superscript letter differ $(P<0.05)$.

${ }^{1} \mathrm{C} 18: 3+\mathrm{C} 20: 5+\mathrm{C} 22: 6$.

${ }^{2} \mathrm{C} 18: 2$ cis- 9 , cis- $12+\mathrm{C} 20: 4$. 


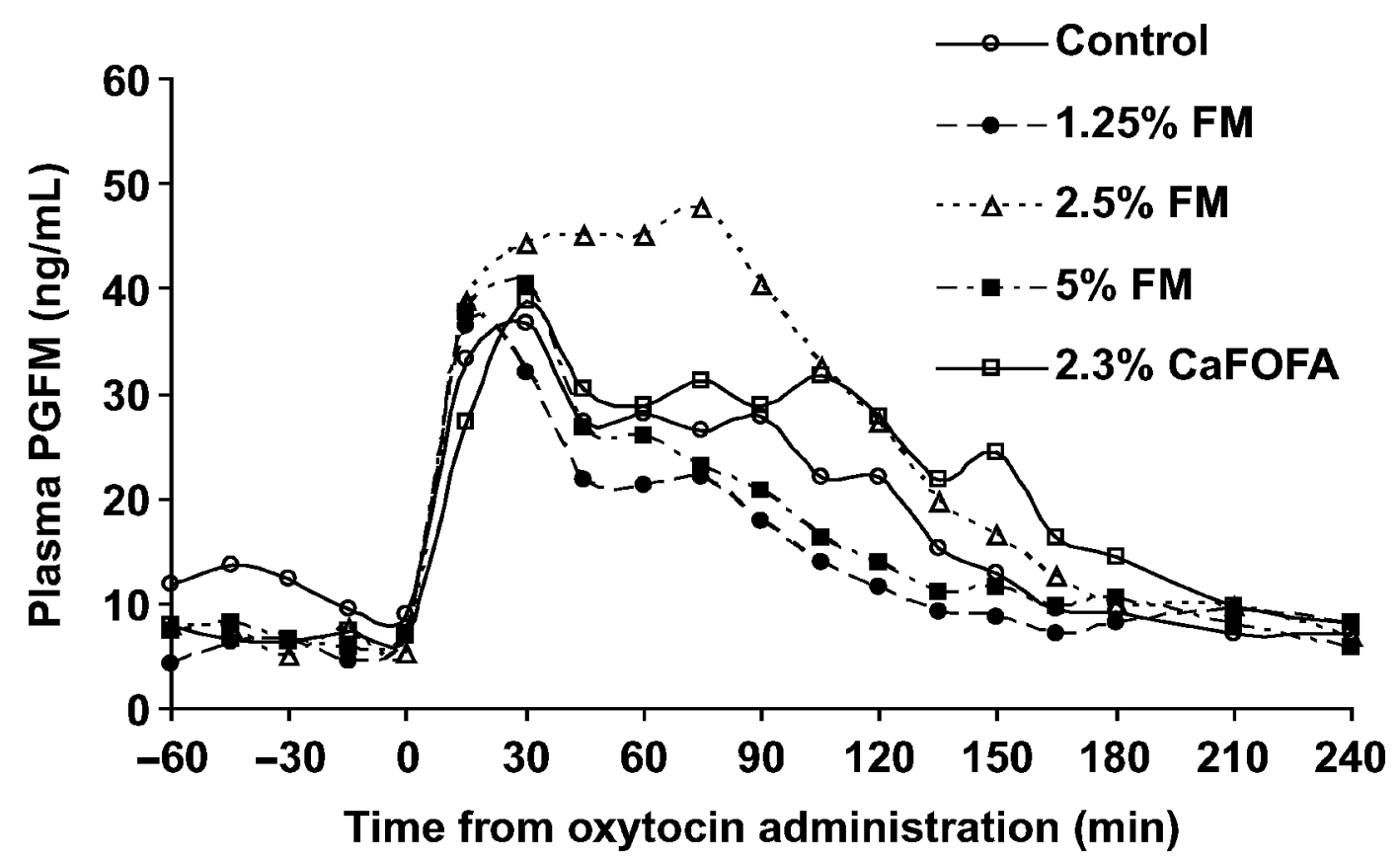

Figure 1. Plasma concentrations of 13,14-dihydro-15-keto $\mathrm{PGF}_{2 \alpha}(\mathrm{PGFM}$; pooled $\mathrm{SE}=3.5 \mathrm{ng} / \mathrm{mL})$ in response to intravenous administration of $100 \mathrm{IU}$ oxytocin in cows fed diets containing fish meal (FM) and Ca salts of fish oil fatty acids (CaFOFA). Effects of diets did not differ $(P=0.42)$.

pected because a number of studies have shown that dietary supplements of FM or fish oil increase rumen production of cis-9, trans-11 CLA and its precursor, vaccenic acid (Bauman et al., 2003). It has been suggested that polyunsaturated fatty acids such as linoleic acid, linolenic acid, EPA, and DHA may inhibit uterine $\mathrm{PGF}_{2 \alpha}$ synthesis through mechanisms such as decreased availability of the precursor ARA; increased competition by these fatty acids with ARA for binding

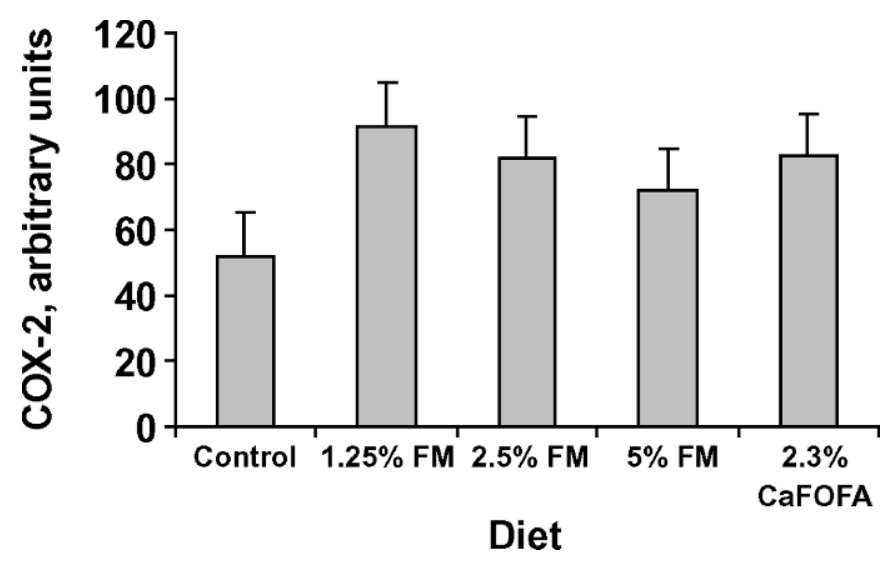

Figure 2. Endometrial cyclooxygenase-2 (COX-2) protein (arbitrary densitometry units) in cows fed diets containing fish meal (FM) and Ca salts of fish oil fatty acids (CaFOFA). Effects of diets did not differ $(P=0.47)$. to PGH synthase; and inhibition of PGH synthase synthesis and activity (Mattos et al., 2000). In addition, it has been shown that CLA inhibits $\mathrm{PGF}_{2 \alpha}$ synthesis in rat uterine tissue independently of linolenic acid and n-6:n-3 ratio (Harris et al., 2001). Results of the present study demonstrated increased availability of n-3 fatty acids and incorporation of EPA, DHA, and CLA into endometrium, but these changes had no significant effect on $\mathrm{PGF}_{2 \alpha}$ production in response to oxytocin. This was especially apparent for cows fed the 5\% FM diet that had both the greatest uterine content of $n-3$ fatty acids and decreased ARA, the immediate precursor of $\mathrm{PGF}_{2 \alpha}$.

Endometrial COX-2 protein abundance was similar among diet treatments. Arosh et al. (2002) demonstrated that during the bovine estrous cycle, COX-2 was expressed throughout the cycle with maximal expression from d 16 to 18 . A recent study shows that most, if not all, prostaglandin production in endometrial tissue is probably processed through COX-2 (Parent et al., 2003) and reduction of $\mathrm{PGH}_{2}$ to $\mathrm{PGF}_{2 \alpha}$ is by $20 \alpha$ hydroxysteroid dehydrogenase (Madore et al., 2003). In the present study, dietary supplementation with FM or CaFOFA resulted in increased endometrial content of EPA, DHA, and CLA, but no difference among diets for COX-2 protein. Endometrial biopsies for COX-2 were collected after the oxytocin challenge, but without other manipulation of the uterus. Our results are con- 
sistent with those of Mattos et al. (2004) showing that concentration of COX-2 protein in caruncular tissue was similar in cows fed fish oil compared with those fed olive oil. In addition, in vitro incubation of bovine endometrial cells for $24 \mathrm{~h}$ with EPA, DHA, or ARA did not affect the concentration of COX-2 and phospholipase $\mathrm{A}_{2}$ protein, but EPA inhibited $\mathrm{PGF}_{2 \alpha}$ secretion (Mattos et al., 2003).

Previous results from feeding FM and fish oil to increase EPA and DHA and effects on $\mathrm{PGF}_{2 \alpha}$ synthesis in dairy cows have been inconsistent. In one study, concentrations of PGFM in plasma were increased for lactating cows receiving formaldehyde-treated linseed oil and fish oil (Petit et al., 2002). In another study, nonlactating heifers were fed FM and no effect was detected in the PGFM response to oxytocin in heifers having a normal luteal progesterone profile and a decreased response only in those with reduced progesterone (Wamsley et al., 2005). On the other hand, results of other studies showed significant inhibitory effects of FM or fish oil on PGFM concentrations (Thatcher et al., 1997; Mattos et al., 2002, 2004). Although our current study used the same range of dietary FM supplementation shown to be inhibitory to $\mathrm{PGF}_{2 \alpha}$ release in previous studies (Thatcher et al., 1997; Mattos et al., 2002), the PGFM response and AUC were not different from control (Figure 1). Compared with a previous study in lactating cows (Mattos et al., 2002), we performed the oxytocin challenge after cows had received FM supplementation for a similar length of time (about 55 vs. 45 $\mathrm{d}$, respectively), but much earlier in lactation (d 160 to 180 vs. d 50, respectively). Whether such differences in stage of lactation have an effect on uterine response to oxytocin has not been determined.

One difference among studies with regard to the effect of FM on PGFM response is whether estradiol was injected before the oxytocin challenge. Estradiol does not seem to change COX-2 expression directly, but rather it can up-regulate the oxytocin receptor, thereby increasing $\mathrm{PGF}_{2 \alpha}$ release (Goff, 2004). Among studies feeding FM, PGFM was attenuated by increased n-3 fatty acids when estradiol injection was included (Mattos et al., 2002), but not when estradiol was omitted (Wamsley et al., 2005; results of the current study). Effect of inclusion of estradiol or not before oxytocin challenge was recently compared in lactating cows and the PGFM response was not different (E. CastanedaGutierrez and W. R. Butler, Cornell, Univ., unpublished observation). This indicates that differences between studies for effect of FM on PGFM response are not accounted for by whether estradiol was used in conjunction with the oxytocin challenge.

Another reason for divergent results in previous studies might be related to different amounts of individual dietary fatty acids besides EPA and DHA that were available for absorption from the gut and transport for uptake by the uterine endometrium. Dietary supplementation with a mixture of fatty acids (palmitic, stearic, oleic, and linoleic acids) would be expected to provide predominantly saturated fatty acids for absorption and resulted in increased plasma PGFM following an oxytocin challenge in lactating dairy cows (Fahey et al., 2002) and beef heifers (Filley et al., 2000). As for unsaturated fatty acids, dietary supplementation with linolenic acid (18:3 n-3) had no significant effects on PGFM concentrations compared with other diets (Petit et al., 2002, 2004; Robinson et al., 2002), whereas supplements containing linoleic acid (18:2 n-6) increased plasma PGFM concentrations (Robinson et al., 2002; Petit et al., 2004). Fahey et al. (2002) suggested that different results among studies might be explained by the fact that linoleic acid can act both as substrate and inhibitor of $\mathrm{PGF}_{2 \alpha}$ synthesis. Consistent with this conclusion, the dose-response pattern with increasing intake of FM and decreasing response of PGFM to oxytocin injection was nonlinear (Mattos et al., 2002). In that study, dietary linoleic acid decreased as FM supplementation increased, but in our current study, the diets were balanced and content of linoleic acid across diets was not different.

Based on the results from a number of studies, it seems possible that shifts in the $n-6: n-3$ ratio in uterine tissue may be the basis for any inhibitory effects and net regulation of $\mathrm{PGF}_{2 \alpha}$ secretion. Differential effects of changing the n-6:n-3 fatty acid ratio in bovine endometrial cell cultures was reported recently (CaldariTorres et al., 2006). Secretion of $\mathrm{PGF}_{2 \alpha}$ was markedly inhibited by preexposure of cells to EPA, but this inhibition was reversed when the endometrial cells were treated with an increasing n-6:n-3 ratio (linoleic:EPA ratio). The results did not further resolve the interacting mechanisms by which fatty acids affect $\mathrm{PGF}_{2 \alpha}$ secretion in the bovine endometrium, but the authors suggested that the net inhibition of $\mathrm{PGF}_{2 \alpha}$ synthesis by n-3 fatty acids may depend on the amount of n- 6 fatty acids reaching the target tissue. In our study, dietary n-3 fatty acid supplementation decreased the n-6:n-3 ratio in the endometrium similar to that rendering marked inhibition of $\mathrm{PGF}_{2 \alpha}$ secretion in the endometrial cultures (Caldari-Torres et al., 2006). Because uterine tissue fatty acid ratio cannot be readily predicted from diet composition because of extensive biohydrogenation and conversion in the rumen (Bauman and Griinari, 2003), regulation of $\mathrm{PGF}_{2 \alpha}$ by altering dietary fatty acid composition in cows remains elusive.

Previous studies have demonstrated that dietary fatty acids can lead to stimulation of ovarian follicle activity (Lucy et al., 1991; Abayasekara and Wathes, 
1999). In the present study dietary fatty acid supplementation had no effect on the size of the preovulatory follicle (day of second $\mathrm{GnRH}$ ) and is consistent with another report (Robinson et al., 2002). The number of 5 - to 10-mm ovarian follicles, however, was affected by diet; on d 10, cows fed the 5\% FM diet had more follicles than those on the other diets.

Because the diets in the present study were formulated to contain similar amounts of lipid, increasing FM and CaFOFA in the present study did not increase the lipid content of the diet and so cholesterol concentrations linked to fatty acid absorption from the gut were similar among diets. Diet had no effect on progesterone and $17 \beta$-estradiol concentrations in this study. We did not find any relationship between plasma progesterone concentration on the day of oxytocin challenge and the PGFM response in cows having a functional $\mathrm{CL}$, in contrast to another recent study using beef heifers (Wamsley et al., 2005). We did observe near absence of the PGFM response for the 3 cows removed from the analyses that had no CL (data not presented).

In conclusion, feeding FM and Ca salts of fish oil fatty acids increased the endometrial content of EPA, DHA, CLA, and total n-3 concentrations and also decreased the $n-6: n-3$ ratio. These changes in endometrial fatty acid composition did not change $\mathrm{PGF}_{2 \alpha}$ secretion based on similarity among diets for PGFM concentrations in response to an oxytocin challenge. Additional research is needed to further define tissue fatty acid composition and ratios necessary for inhibitory effects on $\mathrm{PGF}_{2 \alpha}$ synthesis.

\section{ACKNOWLEDGMENTS}

Fish meal used in this study was generously donated by Omega Protein (Hammond, LA) and the EnerG II and EnerG II Repro were generously provided by Virtus Nutrition (Fairlawn, OH). These companies also provided financial support for the study. The authors thank the staff of the Teaching and Research Center of Cornell University for their assistance in this experiment and excellent care of the cows. AliReza Heravi Moussavi was partially supported by the Iranian Ministry of Science, Research, and Technology for living expenses during his work at Cornell University.

\section{REFERENCES}

Abayasekara, D. R., and D. C. Wathes. 1999. Effects of altering dietary fatty acid composition on prostaglandin synthesis and fertility. Prostaglandins Leukot. Essent. Fatty Acids 61:275-287.

Arosh, J. A., J. Parent, P. Chapdelaine, J. Sirois, and M. A. Fortier. 2002. Expression of cyclooxygenases 1 and 2 and prostaglandin $\mathrm{E}$ synthase in bovine endometrial tissue during the estrous cycle. Biol. Reprod. 67:161-169.

Bauman, D. E., B. A. Corl, and D. G. Peterson. 2003. The biology of conjugated linoleic acids in ruminants. Pages 146-173 in Ad- vances in Conjugated Linoleic Acid Research. Vol. II. J. L. Sébédio, W. W. Christie, and R. Adlof, ed. AOCS Press, Champaign, IL.

Bauman, D. E., and J. M. Griinari. 2003. Nutritional regulation of milk fat synthesis. Annu. Rev. Nutr. 23:203-227.

Beam, S. W., and W. R. Butler. 1997. Energy balance and ovarian follicle development prior to the first ovulation postpartum in dairy cows receiving three levels of dietary fat. Biol. Reprod. 56:133-142.

Burke, J. M., C. R. Staples, C. A. Risco, R. L. de la Sota, and W. W. Thatcher. 1997. Effect of ruminant grade menhaden fish meal on reproductive and productive performance of lactating dairy cows. J. Dairy Sci. 80:3386-3398.

Burns, P. D., T. E. Engle, M. A. Harris, R. M. Enns, and J. C. Whittier. 2003. Effect of fish meal supplementation on plasma and endometrial fatty acid composition in nonlactating beef cows. J. Anim. Sci. 81:2840-2846.

Butler, S. T., A. L. Marr, S. H. Pelton, R. P. Radcliff, M. C. Lucy, and W. R. Butler. 2003. Insulin restores GH responsiveness during lactation-induced negative energy balance in dairy cattle: Effects on expression of IGF-I and GH receptor 1A. J. Endocrinol. 176:205-217.

Caldari-Torres, C., C. Rodriguez-Sallaberry, E. S. Greene, and L. Badinga. 2006. Differential effects of n-3 and n-6 fatty acids on prostaglandin $\mathrm{F}_{2 \alpha}$ production by bovine endometrial cells. J. Dairy Sci. 89:971-977.

Chouinard, P. Y., L. Corneau, A. Saebo, and D. E. Bauman. 1999. Milk yield and composition during abomasal infusion of conjugated linoleic acids in dairy cows. J. Dairy Sci. 82:2737-2745.

Danet-Desnoyers, G., M. D. Meyer, T. S. Gross, J. W. Johnson, and W. W. Thatcher. 1995. Regulation of endometrial prostaglandin synthesis during early pregnancy in cattle: Effects of phospholipases and calcium in vitro. Prostaglandins 50:313-330.

Elrod, C. C., and W. R. Butler. 1993. Reduction of fertility and alteration of uterine $\mathrm{pH}$ in heifers fed excess ruminally degradable protein. J. Anim. Sci. 71:694-701.

Fahey, J., J. F. Mee, J. J. Murphy, and D. O'Callaghan. 2002. Effects of calcium salts of fatty acids and calcium salt of methionine hydroxy analogue on plasma prostaglandin $\mathrm{F}_{2 \alpha}$ metabolite and milk fatty acid profiles in late lactation Holstein-Friesian cows. Theriogenology 58:1471-1482.

Filley, S. J., H. A. Turner, and F. Stormshak. 2000. Plasma fatty acids, prostaglandin $\mathrm{F}_{2 \alpha}$ metabolite, and reproductive response in postpartum heifers fed rumen bypass fat. J. Anim. Sci. 78:139-144.

Fox, D. G., L. O. Tedeschi, T. P. Tylutki, J. B. Russell, M. E. Van Amburgh, L. E. Chase, A. N. Pell, and T. R. Overton. 2004. The Cornell Net Carbohydrate and Protein System model for evaluating herd nutrition and nutrient excretion. Anim. Feed Sci. Technol. 112:29-78.

Goff, A. K. 2004. Steroid hormone modulation of prostaglandin secretion in the ruminant endometrium during the estrous cycle. Biol. Reprod. 71:11-16.

Hara, A., and N. S. Radin. 1978. Lipid extraction of tissues with a low-toxicity solvent. Anal. Biochem. 90:420-426.

Harris, M. A., R. A. Hansen, P. Vidsudhiphan, J. L. Koslo, J. B. Thomas, B. A. Watkins, and K. G. Allen. 2001. Effects of conjugated linoleic acids and docosahexaenoic acid on rat liver and reproductive tissue fatty acids, prostaglandins and matrix metalloproteinase production. Prostaglandins Leukot. Essent. Fatty Acids 65:23-29.

Heravi Moussavi, A. R., R. O. Gilbert, T. R. Overton, D. E. Bauman, and W. R. Butler. 2007. Effects of feeding fish meal and n-3 fatty acids on milk yield and metabolic responses in early lactating dairy cows. J. Dairy Sci. 90:136-144.

Lucy, M. C., C. R. Staples, F. M. Michel, and W. W. Thatcher. 1991. Energy balance and size and number of ovarian follicles detected by ultrasonography in early postpartum dairy cows. J. Dairy Sci. 74:473-482.

Madore, E., N. Harvey, J. Parent, P. Chapdelaine, J. A. Arosh, and M. A. Fortier. 2003. An aldose reductase with 20 alpha-hydroxysteroid dehydrogenase activity is most likely the enzyme responsi- 
ble for the production of prostaglandin $\mathrm{F}_{2 \alpha}$ in the bovine endometrium. J. Biol. Chem. 278:11205-11212.

Mattos, R., A. Guzeloglu, L. Badinga, C. R. Staples, and W. W. Thatcher. 2003. Polyunsaturated fatty acids and bovine interferon- $\tau$ modify phorbol ester-induced secretion of prostaglandin $\mathrm{F}_{2 \alpha}$ and expression of prostaglandin endoperoxide synthase- 2 and phospholipase-A2 in bovine endometrial cells. Biol. Reprod. 69:780-787.

Mattos, R., C. R. Staples, A. Arteche, M. C. Wiltbank, F. J. Diaz, T. C. Jenkins, and W. W. Thatcher. 2004. The effects of feeding fish oil on uterine secretion of $\mathrm{PGF}_{2 \alpha}$ milk composition, and metabolic status of periparturient Holstein cows. J. Dairy Sci. 87:921-932.

Mattos, R., C. R. Staples, and W. W. Thatcher. 2000. Effects of dietary fatty acids on reproduction in ruminants. Rev. Reprod. 5:38-45.

Mattos, R., C. R. Staples, J. Williams, A. Amorocho, M. A. McGuire, and W. W. Thatcher. 2002. Uterine, ovarian, and production responses of lactating dairy cows to increasing dietary concentrations of menhaden fish meal. J. Dairy Sci. 85:755-764.

McCracken, J. A., E. E. Custer, and J. C. Lamsa. 1999. Luteolysis: A neuroendocrine-mediated event. Physiol. Rev. 79:263-323.

Meyer, M. D., P. J. Hansen, W. W. Thatcher, M. Drost, L. Badinga, R. M. Roberts, J. Li, T. L. Ott, and F. W. Bazer. 1995. Extension of corpus luteum lifespan and reduction of uterine secretion of prostaglandin $\mathrm{F}_{2 \alpha}$ of cows in response to recombinant interferon$\tau$. J. Dairy Sci. 78:1921-1931.

Parent, J., C. Villeneuve, and M. A. Fortier. 2003. Evaluation of the contribution of cyclooxygenase 1 and cyclooxygenase 2 to the production of $\mathrm{PGE}_{2}$ and $\mathrm{PGF}_{2 \alpha}$ in epithelial cells from bovine endometrium. Reproduction 126:539-547.

Petit, H. V., R. J. Dewhurst, N. D. Scollan, J. G. Proulx, M. Khalid, W. Haresign, H. Twagiramungu, and G. E. Mann. 2002. Milk production and composition, ovarian function, and prostaglandin secretion of dairy cows fed omega-3 fats. J. Dairy Sci. 85:889-899.

Petit, H. V., C. Germiquet, and D. Lebel. 2004. Effect of feeding whole, unprocessed sunflower seeds and flaxseed on milk production, milk composition, and prostaglandin secretion in dairy cows. J. Dairy Sci. 87:3889-3898.

Ringbom, T., U. Huss, A. Stenholm, S. Flock, L. Skattebol, P. Perera, and L. Bohlin. 2001. Cox-2 inhibitory effects of naturally occurring and modified fatty acids. J. Nat. Prod. 64:745-749.

Robinson, R. S., P. G. Pushpakumara, Z. Cheng, A. R. Peters, D. R. Abayasekara, and D. C. Wathes. 2002. Effects of dietary polyunsaturated fatty acids on ovarian and uterine function in lactating dairy cows. Reproduction 124:119-131.

Staples, C. R., J. M. Burke, and W. W. Thatcher. 1998. Influence of supplemental fats on reproductive tissues and performance of lactating cows. J. Dairy Sci. 81:856-871.

Thatcher, W. W., M. Binelli, J. Burke, C. R. Staples, J. D. Ambrose, and S. Coelho. 1997. Antiluteolytic signals between the conceptus and endometrium. Theriogenology 47:131-140.

Wamsley, N. E., P. D. Burns, T. E. Engle, and R. M. Enns. 2005. Fish meal supplementation alters uterine prostaglandin $\mathrm{F}_{2 \alpha}$ synthesis in beef heifers with low luteal-phase progesterone. J. Anim. Sci. 83:1832-1838.

Weber, P. C., and A. Sellmayer. 1991. Modification of the eicosanoid system and cell signalling by precursor fatty acids. Adv. Prostaglandin Thromboxane Leukot. Res. 21A:217-224.

Yavas, Y., W. H. Johnson, and J. S. Walton. 1999. Modification of follicular dynamics by exogenous FSH and progesterone, and the induction of ovulation using hCG in postpartum beef cows. Theriogenology 52:949-963. 